\title{
A kaleidoscope of mammal, bird and fish: habitat use patterns of top predators and their prey in Florida Bay
}

\author{
Leigh G. Torres ${ }^{1,2, *}$ \\ ${ }^{1}$ Duke University Marine Laboratory, Nicholas School of the Environment and Earth Sciences, \\ 135 Duke Marine Lab Road, Beaufort, North Carolina 28516, USA \\ ${ }^{2}$ Present address: National Institute of Water and Atmospheric Research (NIWA), 301 Evans Bay Parade, Greta Point, \\ Private Bag 14-901, Kilbirnie, Wellington 6021, New Zealand
}

\begin{abstract}
Habitat selection by top predators that are largely free from predation pressures is a function of prey availability and interspecific competition. Such competition can be minimized through niche dimensions: mechanism of resource partitioning based on prey choice and foraging tactic. This study compared habitat use patterns of 5 top predators (bottlenose dolphins, doublecrested cormorants, osprey, brown pelicans and terns) within Florida Bay with respect to each other, their prey and habitat variability. Foraging dolphins, osprey and pelicans exhibited similar habitat use patterns in shallow, turbid, productive waters with high proportions of mud and mudbank bottom types. These same habitat characteristics also described the distribution of their major prey items: mullet and catfish. Competition between these 3 predators is likely diluted by foraging tactic variation. Conversely, the habitat use patterns of cormorants showed strongest association with deeper water, with low chlorophyll $a$ and turbidity levels, less mud and mudbank habitat, and greater proportions of hardbottom and seagrass bottoms. Those prey items of cormorants with less competition from other predators examined displayed the same habitat associations. Cormorants in Florida Bay may concentrate their foraging efforts on less competitive prey, occurring more frequently in habitats where these prey items dominate. Despite Florida Bay's limited bathymetric relief, habitat use patterns of top predators are significantly influenced by depth, and subsequently bottom type. Sighting rates of all predators, except non-foraging dolphins, peaked in shallow mudbank habitats. This pattern of strong habitat overlap among predators implies currently adequate resource availability and/or niche dimensions among interspecific competitors.
\end{abstract}

KEY WORDS: Habitat use · Competition · Foraging tactics · Seabirds · Bottlenose dolphin · Habitat structure $\cdot$ Niche overlap $\cdot$ Nonmetric multidimensional scaling

Resale or republication not permitted without written consent of the publishe

\section{INTRODUCTION}

In marine ecosystems, predation is a significant determinant of species distribution (Heck \& Orth 1980). The habitat selection patterns by predators are a function of both prey availability and resource competition (Fretwell \& Lucas 1970, Schoener 1971). Species with similar requirements can reduce interspecific competition through disparate distribution patterns (MacArthur 1958, Connell 1961) to carve out distinct habitat niches. Such interspecific competition for resources can vary in intensity and the number of species involved. MacArthur (1972) defined the term 'diffuse competition' to mean the cumulative competitive effects of a number of interspecific competitors within an ecosystem. Competition between predators can be reduced by targeting different prey items, different prey sizes or prey in different habitats, or using different foraging tactics. These methods of prey partitioning act as 'niche dimensions' to reduce competition 
and facilitate coexistence among interspecific competitors: the greater the number of niche dimensions, the greater potential for diffuse competition (Pianka 1974).

May \& MacArthur (1972) examined niche overlap between species as a function of environmental variability in an ecosystem with strong, constant competition for a resource. Pianka (1974) built upon this work to describe his 'niche overlap hypothesis', applicable when the supply of resources is variable. Pianka (1974) illustrated that interspecific niche overlap does not imply competition, but rather when resources are plentiful, organisms can share them without conflict (high niche overlap = reduced competition). Conversely, disparate niches between competitors indicates competition avoidance when resources are scarce (low niche overlap = increased competition).

Comparative habitat use studies between seabird species or assemblages in relation to environmental conditions and foraging tactics have primarily been conducted in pelagic environments (Jaquemet et al. 2005, Hyrenbach et al. 2006, 2007, Vilchis et al. 2006). Comparable studies in coastal ecosystems are rare (Baltz \& Morejohn 1977, Skov \& Prins 2001). Of all these studies, only one included mammal competitors (Skov et al. 1995) or direct data on prey distribution or diets (Baltz \& Morejohn 1977) in the analyses. The present study attempts to distinguish habitat use patterns of 5 seabird species groups and 1 dolphin species relative to each other, their prey fields and their environment within a dynamic coastal ecosystem.

Data were collected during systematic surveys in Florida Bay on the distribution of 5 top predator groups: bottlenose dolphins Tursiops truncatus, double-crested cormorants Phalacrocorax auritus, osprey Pandion haliaetus, brown pelicans Pelecanus occidentalis and terns (family Laridae). These data were combined with synoptic fish and environmental sampling to address 2 questions: (1) Do these top predator groups in Florida Bay exhibit habitat separation or overlap? (2) Do the habitat characteristics and distribution patterns of these predator groups correspond with those of each predator's major prey items? These predators utilize different foraging tactics to locate and capture their prey and, while the prey items and sizes of these predators are diverse, there is overlap. Although it is unknown if any prey items are a limiting resource for these predators in Florida Bay, the potential for resource competition and the means of prey partitioning between predators are considered.

Due to the complexities of scale-dependent predator-prey interactions of both seabirds and marine mammals with their prey fields (Schneider \& Piatt 1986, Fauchald et al. 2000, Vlietstra 2005, Redfern et al. 2006, Torres et al. in press), spatial scale is essentially removed from this analysis. Rather, habitat use patterns are established by comparing and contrasting the habitat characteristics at the time and location each predator species was observed and each prey item was captured. The Florida Bay landscape is a diverse mosaic of habitat types that fosters a heterogeneous community of prey. This diversity of habitats provides a variety of refuges for prey and foraging opportunities for predators. Due to the important role habitat variability plays in predator and prey distributions in marine ecosystems (Heck \& Orth 1980), the influence of habitat structure on predator and prey distribution in Florida Bay is closely examined.

A few important assumptions were made in the present study: (1) prey items do not significantly shift habitat use patterns relative to predator distribution over the temporal scale examined ${ }_{i}(2)$ there is minimal predation on the top predators examined that would affect their habitat use patterns (including a low abundance of shark species that pose a predation risk to dolphins; Torres et al. 2006, Wiley \& Simpfendorfer 2007); and (3) competition from other top predators in Florida Bay (sharks, tarpon, large piscivorous fish) for similar prey items is minimal and does not influence the habitat use patterns of the predators or prey examined.

\section{MATERIALS AND METHODS}

Study site. Florida Bay lies at the southern tip of the Florida peninsula, has an area of approximately $1800 \mathrm{~km}^{2}$, and is composed of a heterogeneous mosaic of benthic habitat types, water quality gradients and floral and faunal communities (Fig. 1). Previous research in Florida Bay subdivided the bay into environmentally distinct zones based on fish composition (Sogard et al. 1989a, Thayer \& Chester 1989), water quality (McIvor et al. 1994, Boyer et al. 1999) and seagrass distribution (Hall et al. 1999). These zone definitions were utilized to divide the bay into 6 relatively homogeneous regions: Atlantic, Central, Eastern, Flamingo, Gulf and Western (Fig. 1, Table 1). Florida Bay is extremely shallow with depths ranging from $<1 \mathrm{~m}$ to $3 \mathrm{~m}$. An extensive network of mudbanks and mangrove islands runs throughout the bay and delineates basins connected through isolated passes and channels. These mudbanks are typically covered with seagrass vegetation.

Field methods. Tracklines were surveyed throughout Florida Bay during the summer months (June, July and August) of 2003, 2004 and 2005. A $17 \mathrm{ft}(5.2 \mathrm{~m})$ Boston Whaler was driven at $\sim 16$ knots with 3 trained observers searching for bottlenose dolphins within any distance range and double-crested cormorants, osprey, brown pelicans, royal terns Sterna maxima, least terns Sterna antillarum and sandwich terns Sterna sandvi- 


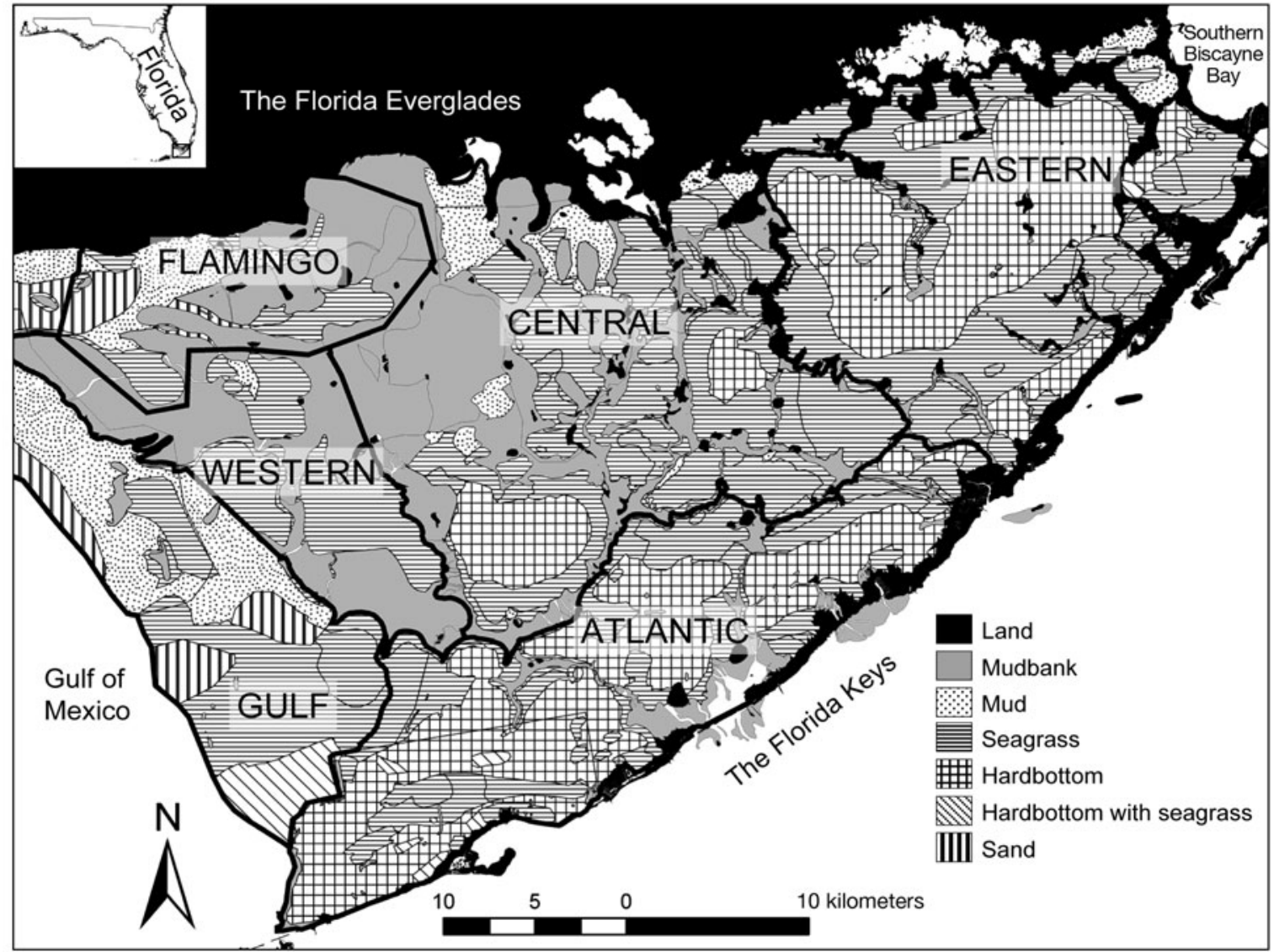

Fig. 1. Bottom types and zones of Florida Bay. Inset: Florida Bay lies at the southern end of the Florida peninsula (area in box enlarged). Thick black lines designate boundaries between the 6 environmentally homogeneous zones. Bottom types map based on Halley \& Prager (1997)

Table 1. Description of 6 environmentally distinct zones in Florida Bay with percentage of bottom types in each zone. HBSG $=$ hardbottom with seagrass

\begin{tabular}{|c|c|c|c|c|c|c|c|}
\hline Zone & Typical characteristics & $\begin{array}{c}\text { Hardbottom } \\
(\%)\end{array}$ & $\begin{array}{c}\text { HBSG } \\
(\%)\end{array}$ & $\begin{array}{c}\text { Mud } \\
(\%)\end{array}$ & $\begin{array}{c}\text { Mudbank } \\
(\%)\end{array}$ & $\begin{array}{l}\text { Sand } \\
(\%)\end{array}$ & $\begin{array}{c}\text { Seagrass } \\
(\%)\end{array}$ \\
\hline Atlantic & $\begin{array}{l}\text { Large passes to Florida Keys reef track, normal } \\
\text { salinity, high water clarity, low productivity, } \\
\text { moderate to deep depth (1.5 to } 3 \mathrm{~m})\end{array}$ & 53 & 1.5 & 0 & 8.5 & 0 & 37 \\
\hline Central & $\begin{array}{l}\text { Locked between mudbanks, moderate to } \\
\text { hyper-saline, low water clarity, high productivity, } \\
\text { shallow depth }(0.5 \text { to } 1.5 \mathrm{~m})\end{array}$ & 9 & 0 & 8 & 39 & 0 & 44 \\
\hline Eastern & $\begin{array}{l}\text { Greatest freshwater inflow, low to moderate salinity, } \\
\text { high water clarity, low productivity, } \\
\text { moderate depth (1.5 to } 2.5 \mathrm{~m})\end{array}$ & 44 & 1 & 3 & 2 & 0 & 50 \\
\hline Flamingo & $\begin{array}{l}\text { Generally shallow }(1 \mathrm{~m}) \text { with one wide deep } \\
\text { channel }(2.5 \mathrm{~m}) \text {, moderate to high salinity, } \\
\text { high productivity, low water clarity }\end{array}$ & 0 & 0 & 17 & 55 & 9 & 19 \\
\hline Gulf & $\begin{array}{l}\text { Open to Gulf of Mexico, moderate salinity, } \\
\text { moderate to low water clarity, } \\
\text { moderate productivity, deep depth (1.5 to } 3 \mathrm{~m})\end{array}$ & 0 & 8 & 34 & 2 & 20 & 36 \\
\hline Western & $\begin{array}{l}\text { Moderate to high salinity, high water clarity, } \\
\text { low to moderate productivity, } \\
\text { moderate depth ( } 1 \text { to } 2 \mathrm{~m})\end{array}$ & 0 & 0 & 1 & 50 & 0 & 49 \\
\hline \multicolumn{2}{|c|}{ All of Florida Bay } & 23 & 2 & 9 & 21 & 4 & 41 \\
\hline
\end{tabular}


censis within a $100 \mathrm{~m}$ radius of the vessel. Water quality and bottom type (see 'Benthic habitat and water quality sampling') were recorded at the start and end of each survey, at each dolphin sighting and every $30 \mathrm{~min}$ if no dolphins were sighted. At all seabird and dolphin sightings, the field crew recorded the GPS location and the behavior state of the animal. Seabirds were classified as either sitting on stoop, sitting on water, flying or feeding. Dolphins were classified as foraging or non-foraging. Dolphins were determined to be foraging if they were observed catching fish, chasing fish, or surfacing erratically and quickly within one area using fluke-out dives to promote deep diving profiles. The species and number of any seabird(s) present at a dolphin sighting were also recorded.

During the 2003 field season, the entirety of Florida Bay was surveyed 2 times to gather baseline information on the distribution of these piscivorous predator

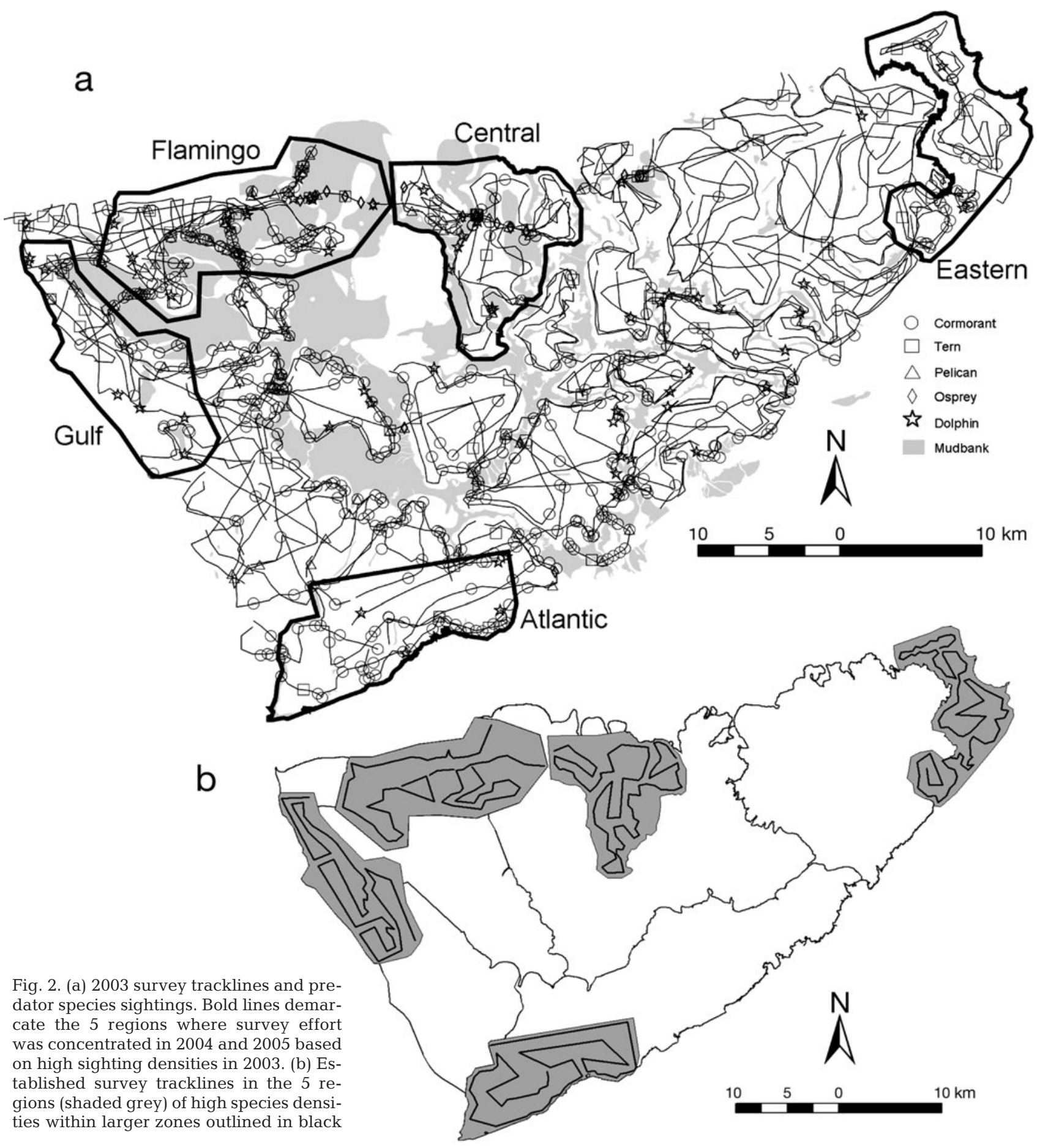


groups (Fig. 2a). Based on the examination of density plots of 2003 predator observations, survey tracklines, each $85 \mathrm{~km}$ long, were established in 5 different zones within areas of relatively high densities of all predator groups (Fig. 2b). While other areas may have had higher densities of some predator group(s), selected areas for intensified survey effort had a mixture of predator group observations, as well as different environmental conditions. Each trackline was surveyed 6 times during 2004 and 2005. This approach was taken to concentrate survey effort in areas of high habitat use by multiple species within a variety of environments, where the possibility of detecting competition and habitat partitioning among the predators increased.

Benthic habitat and water quality sampling. The United States Geological Society (USGS) produced a bottom types map of Florida Bay in 1997 (Halley \& Prager 1997). This map was used as the foundation for benthic habitat classification throughout Florida Bay. To refine this map, benthic habitat type was assessed and recorded at all water and habitat quality sampling locations. These 1092 sampling locations were used to update and improve the resolution of the original USGS map (Fig. 1). Habitat types were classified by visual inspection (through the water column) or, when turbidity did not allow this, use of a small bottom grab sampler (5 $\mathrm{cm}$ diameter; $7.6 \mathrm{~cm}$ deep). The same classification system used by the USGS map was implemented with the addition of one class, 'hardbottom with seagrass', which were areas composed of equal amounts of sponge and coral habitat as seagrass habitat. Thus, for this analysis, 6 bottom type classifications were established: seagrass (all sparse, intermediate and dense seagrass habitats), mud, mudbank, sand, hardbottom and hardbottom with seagrass.

In 2003, a YSI 30 instrument was used to measure salinity (ppt) and temperature $\left({ }^{\circ} \mathrm{C}\right)$ at the mid-point of the water column. To estimate turbidity and chlorophyll a (chl a) values during this year, data were acquired through the Southeast Environmental Research Center's (SERC) Water Quality Monitoring Network. This program has 24 water quality stations with monthly sampling periods placed throughout Florida Bay. Using ArcGIS (v. 9.1, ESRI), these data points were interpolated with an inverse distance weighting (IDW) technique, which preserves local variation between sample points. In total, 6 separate rasters were created: 1 grid for each variable (turbidity and chl a) for each month of the study period (June, July and August 2003).

During the 2004 and 2005 field seasons, the following water quality metrics were recorded in the upper and lower $0.5 \mathrm{~m}$ of the water column using a YSI 6600 sonde: temperature $\left({ }^{\circ} \mathrm{C}\right)$, salinity (ppt), turbidity (nephelometer turbidity units [NTU]) and chl $a$. The average value of the upper and lower water column measurements was used for each location in the following analyses because no discernable difference was detected between water samples from the well mixed, shallow waters of Florida Bay. At a minimum of 2 sites in each zone, water samples were obtained and filtered to calibrate the YSI-based chl a fluoresence readings. Water samples were filtered with Whatman GF/F $25 \mathrm{~mm}$ diameter filters with nominal porosity of $0.7 \mu \mathrm{m}$. These filters were later extracted in the laboratory and a Turner Designs Fluorometer was used to make absolute chl a readings. From these readings, a linear regression model was developed to convert the YSI chl a readings into actual $\mathrm{chl}$ a $\left(\mu \mathrm{g} \mathrm{l}^{-1}\right)$ values. Water samples for chl a were collected at 12 spatially and temporally distributed sites in 2004 and 7 sites in 2005 (Fig. 3), with filters extracted from 3 subsamples collected at each site. Each subsample of $500 \mathrm{ml}$ was extracted for $24 \mathrm{~h}$ and assessed using the fluorometer.

Water quality sampling points from each survey day were interpolated into rasters of daily temperature, salinity, chl a and turbidity variation over the spatial extent of each survey. (Monthly interpolations were created for chl a and turbidity in 2003, as described 2 paragraphs above.) To create each raster, a kriging method was used to accurately interpolate spatial trends between data points and a fine spatial scale of $50 \mathrm{~m}$ grid cell size was applied. Rasters of static variables depth, bottom type and distance from mudbank (Euclidean) were also composed with a $50 \mathrm{~m}$ grid cell size.

Species diets. An extensive literature search on the diets of the studied predator species was conducted in order to facilitate realistic comparisons between the habitat use patterns of the predator groups and their potential prey items. Unfortunately, information on the diets of these predators in Florida Bay was only available for osprey. Diet information on the other predators was gathered from studies in geographically adjacent areas in Florida, except for terns, for which diet information was very limited (Table 2).

Fish sampling. Because of the diversity of fish distributed throughout Florida Bay and catch biases associated with each fish sampling method, 3 different methods were used to sample the fish community. The primary method used a $3 \mathrm{~m}$ research otter trawl towed at $\sim 4 \mathrm{~km} \mathrm{~h}^{-1}$ for $3 \mathrm{~min}$. Between 2003 and 2005, 268 trawls were conducted. The location of each trawl site was randomly generated, and stratified by benthic habitat type, to sample the different bottom types within each zone (Fig. 3). A minimum of 3 trawls were conducted on each survey day. Secondly, because many faster, larger fish could out-swim the bottom trawl, a $100 \mathrm{~m}$ gillnet, composed of one $50 \mathrm{~m}$ panel of $7.6 \mathrm{~cm}$ mesh and another of $8.9 \mathrm{~cm}$ mesh, was soaked 


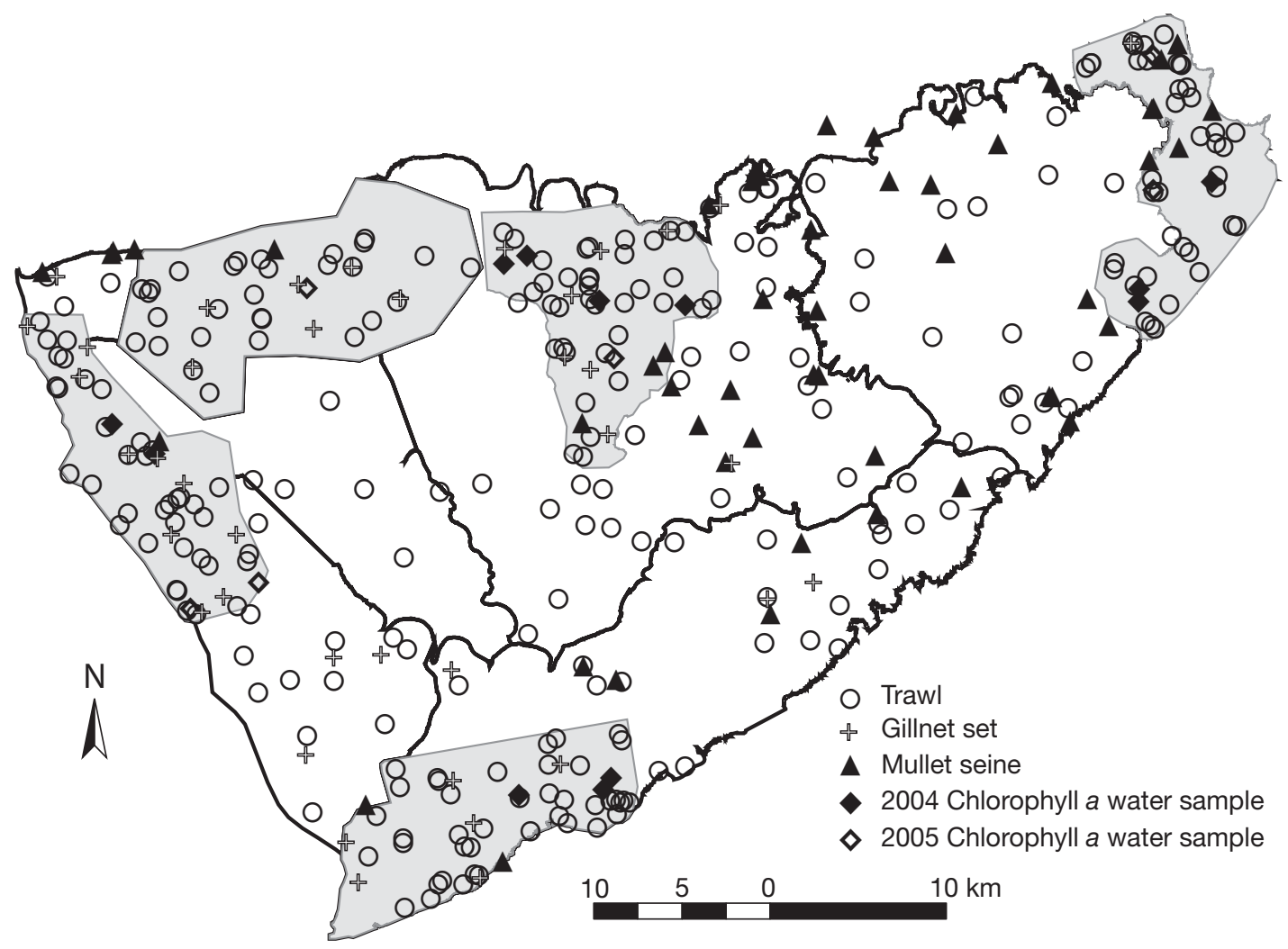

Fig. 3. Locations of fish sampling (2003 to 2005) and chl a water samples (2004 to 2005). Regions of concentrated survey effort during 2004 and 2005 field seasons are shown in grey within larger zones outlined in black

Table 2. Frequency of prey groups in predator diets in Florida Bay based on a literature review. Catch frequency indicates frequency prey groups were caught in fish sampling. Bottlenose dolphin diet references: Barros (1987, 1993), Barros \& Wells (1998) (South Florida \& SE USA). Brown pelican diet references: Audubon (1972), Fogarty et al. (1981) (Florida). Osprey diet references: Ogden (1973, 1978), Poole (1989) (Florida Bay \& Florida). Double-crested cormorant diet references: Cummings (1987) (Biscayne Bay, Florida). Tern diet references: Bent (1921), McGinnis \& Emslie (2001) (general diet: North Carolina). C = common, $\mathrm{M}=$ moderate, $\mathrm{R}=$ rare, $\mathrm{FWC}=$ data supplied by the Florida Fish and Wildlife Conservation Commission. Dashes indicate no record of occurrence

\begin{tabular}{|c|c|c|c|c|c|c|}
\hline & $\begin{array}{l}\text { Bottlenose } \\
\text { dolphin }\end{array}$ & $\begin{array}{l}\text { Brown } \\
\text { pelican }\end{array}$ & Osprey & $\begin{array}{l}\text { Double- } \\
\text { crested } \\
\text { cormorant }\end{array}$ & $\begin{array}{c}\text { Tern } \\
\text { (royal, least, } \\
\text { sandwich) }\end{array}$ & $\begin{array}{l}\text { Catch } \\
\text { frequency }\end{array}$ \\
\hline Family Ariidae (gafftopsail \& hardhead catfish) & $\mathrm{C}$ & - & $\mathrm{C}$ & - & - & $\mathrm{C}$ \\
\hline Family Atherinidae (silversides) & - & M & - & - & $\mathrm{C}$ & $\mathrm{R}$ \\
\hline Family Carangidae (jacks) & M & $\mathrm{R}$ & $\mathrm{C}$ & - & - & M \\
\hline $\begin{array}{l}\text { Family Cyprinodontidae (killifish \& } \\
\text { sheepshead minnow) }\end{array}$ & - & $\mathrm{R}$ & - & - & - & $\mathrm{C}$ \\
\hline Family Gerreidae (mojarra) & $\mathrm{C}$ & $\mathrm{R}$ & - & - & - & $\mathrm{C}$ \\
\hline Family Haemulidae (grunts \& pigfish) & $\mathrm{C}$ & $\mathrm{R}$ & - & $\mathrm{C}$ & - & $\mathrm{C}$ \\
\hline Family Labridae (wrasses \& hogfish) & $\mathrm{R}$ & - & - & M & - & $\mathrm{R}$ \\
\hline Family Lutjanidae (snapper) & - & - & - & M & - & M \\
\hline Family Monachanthidae (filefish) & - & - & $\mathrm{R}$ & M & - & $\mathrm{C}$ \\
\hline Family Mugilidae (striped \& white mullet) & $\mathrm{C}$ & $\mathrm{C}$ & $\mathrm{C}$ & - & - & FWC \\
\hline Family Scaridae (Parrotfish) & - & - & - & $\mathrm{C}$ & - & M \\
\hline Family Sciaenidae (silver perch \& spotted seatrout) & $\mathrm{C}$ & M & M & - & - & M \\
\hline Family Sparidae (pinfish \& porgies) & $\mathrm{C}$ & M & $\mathrm{R}$ & M & - & $\mathrm{C}$ \\
\hline Opsanus beta (gulf toadfish) & $\mathrm{C}$ & $\mathrm{R}$ & - & $\mathrm{C}$ & - & $\mathrm{C}$ \\
\hline Order Clupeiforms (herring, sardines \& anchovy) & - & $\mathrm{C}$ & - & - & $\mathrm{C}$ & $\mathrm{R}$ \\
\hline
\end{tabular}


for $30 \mathrm{~min}$. These gillnet sets were constantly monitored during soak times and were also stratified by bottom type and zone. These gillnet data provided a description of the distribution of larger, faster fish throughout Florida Bay. A total of 50 gillnet sets were conducted in 2003, and 32 sets in 2004. No gillnet sets were performed in 2005. All captured fish from trawls and gillnet sets were identified, measured, and then released. GPS position and all water and habitat quality metrics were recorded prior to each trawl and gillnet set.

Due to the speed and patchiness of mullet, only 1 mullet was caught in the 82 gillnet sets, which is highly unrepresentative of the large abundance of mullet in Florida Bay (Scott et al. 1989). Fortunately, data on the distribution of mullet Mugil spp. was collected by the Fisheries Independent Monitoring Program of the Florida Fish and Wildlife Conservation Commission in Florida Bay during June, July and August 1997 and August 2006 using a $183 \mathrm{~m}$ haul seine (FWC-FWRI 2007). Due to the importance of mullet in the diets of dolphins, osprey and pelicans in Florida Bay, data from these mullet seines were incorporated into this analysis to provide a description of their habitat use patterns. Depth, temperature, salinity, GPS location and number of mullet caught were provided by the FWC for each sampling location. Chl $a$ and turbidity values were obtained through interpolated rasters of data provided by the SERC Water Quality Monitoring Network during the same monthly time period in 1997 and 2006. A backwards-step generalized additive model (GAM) was run on these data to describe the nonlinear relationship between mullet catch and the environmental characteristics at each sampling site.

Analyses. Royal terns, least terns and sandwich terns target similar prey items (Bent 1921) and therefore were grouped into a single 'tern' group to increase sample size. Only $4 \%$ of all seabird sightings consisted of feeding activity and this percentage decreased further when categorized by species. Therefore, birds were not grouped by behavior. Foraging was observed at $28 \%$ of dolphin sightings, allowing a big enough sample size to have 2 groups of dolphins: foraging and non-foraging. The following analyses were conducted on 6 predator groups: double-crested cormorants (910 groups of 1985 ind.), brown pelicans (161 groups of 234 ind.), osprey (72 groups of 96 ind.), terns (161 groups of 229 ind.), foraging bottlenose dolphins (53 groups of 375 ind.) and non-foraging bottlenose dolphins (111 groups of 765 ind.).

A 3-way ANOVA was performed on the sighting rates of the 6 predator groups. The 3 factors tested were year, zone and bottom type. Survey routes, buffered $100 \mathrm{~m}$ on each side (survey range for seabirds), were used to sum the amount of survey effort $\left(\mathrm{km}^{2}\right)$ in each year-zone-bottom type combination. The number of sightings of each predator group in each of these yearzone-bottom type combinations was tabulated and divided by the amount of survey effort. These data were log-transformed to conduct the 3-way ANOVA.

Although data on the distribution of seabirds and dolphins in Florida Bay were collected as points, ordinations must be run on plot data. Therefore, species point data were compiled into plot data using ArcGIS. Each survey route from 2003, 2004 and 2005 was divided into $1 \mathrm{~km}$ segments and buffered on each side to $100 \mathrm{~m}$ (the survey distance for seabirds). These $1 \mathrm{~km}$ $\times 200 \mathrm{~m}$ segments became plots. The number and species of each sighting that fell in each plot was tabulated. Any plot with no sightings was eliminated from the dataset. The average value of depth, distance from mudbank, and each water quality metric (temperature, salinity, chl a and turbidity) of each plot was determined, as was the percentage of bottom type cover. These environmental factors were examined because of their potential ecological influence on the distribution of predators and prey. These variables have been demonstrated to affect the abundance, distribution and densities of fish in Florida Bay (Holmquist et al. 1989b, Scott et al. 1989, Sogard et al. 1989a, 1989b, Thayer \& Chester 1989, Thayer et al. 1999). As potential predators of fish prey items, the habitat use patterns of dolphins and seabirds are also likely to correlate with these variables. Finally, the centroid of each plot was calculated and used as its spatial location. A total of 1275 plots were analyzed.

Mantel tests (Mantel 1967) were used to identify those explanatory variables significantly correlated with the distribution of the 6 predator groups. Mantel tests are able to overcome many problems associated with examining species-environment relationships because they are multivariate, explicitly test for the effect of space on the response variable, account for the effects of multicolinearity between predictor variables, and identify and account for spatial autocorrelation of explanatory variables. Mantel tests were run in S-Plus (v. 7.0, Insightful) on the plot data with presence/absence of a predator group as the response variable. The tested explanatory variables were: (1) the plot average values of chl a, salinity, temperature, turbidity, depth, and distance from mudbank ( $\log +1)$, (2) the proportion of each plot covered by seagrass, mudbank, mud, sand, hardbottom, or hardbottom with seagrass and (3) zone (converted to dummy variables). To reduce the number of variables assessed by the ordinations (see next paragraph), only those variables with a significant relationship to predator group presence/absence from the Mantel tests were incorporated. Ordinations do not account for spatial autocorrelation. Therefore, the use of Mantel tests as a preliminary step to ordinations allows 
more confidence in the resulting ordination plots of predator groups within habitat space.

Nonmetric multidimensional scaling (NMDS) (Shepard 1962, Kruskal 1964) was used to describe the association between the 6 predator groups and the set of environmental variables identified by the Mantel tests as significant. An NMDS is a non-parametric ordination that is free from assumptions about linearity, dimensionality of the data, or underlying species responses to gradients. Each axis describes a gradient of habitat characteristics so that samples are plotted in habitat space to preserve the relative pairwise ecological distance among samples. Predator groups and samples from similar habitats are plotted closer together in ordination space. The statistical software package PC-ORD (McCune \& Mefford 1999) was used to conduct all NMDS analyses and to create plots of species distributions in habitat space. The number of axes was chosen based on the results of a step-down procedure and Monte Carlo tests to achieve low stress and stable solutions. A Sorensen (Bray-Curtis) distance measure was used to create the distance matrices.

An NMDS was used to describe the habitat association patterns of the 6 predator groups within 1275 plots. The continuous variables (depth, distance from mudbank $[\log +1]$, salinity, temperature, chl a, turbidity) were transformed using a general relativization $(p=1)$ and the proportional data (percent plot cover of each bottom type) was transformed with an arcsine square-root transformation.

Ecological community datasets are typically plagued by a large number of zeros. Beals (1984) referred to this as the 'zero truncation problem' and developed a data transformation method for such sparse community matrices that replaces binomial data points with probabilities of occurrence based on the pattern of co-occurrences in the matrix (McCune 1994). Beals smoothing, as this transformation is called, is effective for heterogeneous data as it reduces the number of zero occurrences and improves the detection of compositional gradients (McCune 1994, Unterseher \& Tal 2006). Beals smoothing was used to reduce the percent of zero occurrences in the predator group dataset from 80 to $1.4 \%$.

Although over 69 fish and 12 invertebrates species were caught using the methods described in 'Fish sampling', catch data used in the ordination analyses were grouped by species or taxonomic family and limited to 14 groups of frequently caught, non-invertebrate fish that are known prey of dolphins, cormorants, pelicans, terns or osprey (Tables $3 \& 4$ ). Trawls and gillnets sets with no catch were excluded from the analysis because an ordination cannot be conducted on a dataset including samples with no species abundance information.

A second NMDS was run on a dataset consisting of 9 fish groups (Table 3) and 216 trawls with the following associated environmental variables: depth, distance from mudbank $(\log +1)$, salinity, temperature, chl $a$, turbidity, year, zone, bottom type. The last 3 variables are categorical and were not included in the matrix but used as grouping variables. Two groups (families Atherinidae and Clupeidae) were initially included in the ordinations but due to infrequent occurrences were identified as outliers. Additionally, the family Cyprinodontidae group was identified as an outlier because

Table 3. Description of fish groups used in trawl nonmetric multidimensional scaling (NMDS)

\begin{tabular}{|c|c|c|c|}
\hline Group name & No. caught & No. of occurrences & Group description \\
\hline Gerreidae & 1915 & 172 & Family Gerreidae (mojarras) \\
\hline Sparidae & 1655 & 122 & Family Sparidae (pinfish \& porgies) \\
\hline Haemulidae & 737 & 78 & Family Haemulidae (grunts \& pigfish) \\
\hline Monachanthidae & 338 & 70 & Family Monacanthidae (filefish) \\
\hline Sciaenidae & 288 & 39 & Family Sciaenidae (silver perch \& spotted seatrout) \\
\hline Lutjanidae & 147 & 61 & Family Lutjanidae (snappers) \\
\hline Opsanus beta & 81 & 51 & Opsanus beta (Gulf toadfish) \\
\hline Scaridae & 77 & 33 & Family Scaridae (parrotfish) \\
\hline Labridae & 59 & 25 & Family Labridae (wrasses \& hogfish) \\
\hline Cyprinodontidae $^{a}$ & 1422 & 233 & Family Cyprinodontidae (killifish \& sheepshead minnow) \\
\hline Atherinidae $^{\mathrm{a}}$ & 67 & 7 & Family Atherinidae (silversides) \\
\hline Clupeidae $^{a}$ & 14 & 6 & Order Clupeidae (herring, sardines \& anchovy) \\
\hline
\end{tabular}

Table 4. Description of fish groups used in gillnet nonmetric multidimensional scaling (NMDS)

\begin{tabular}{|lccl|}
\hline Group name & No. caught & No. of occurrences & Group description \\
\hline Ariidae & 72 & 23 & Family Ariidae (gafftopsail \& hardhead catfish) \\
Carangidae & 21 & 9 & Family Carangidae (jacks) \\
\hline
\end{tabular}


of its predominance in a small number of trawls. Therefore these 3 groups were removed from the trawl dataset. A third NMDS was conducted on 2 groups of fish, families Ariidae (catfish) and Carangidae (jacks), that were caught in 27 gillnets sets. These fish are important prey items of dolphins, osprey and occasionally brown pelicans, and were not caught in trawl samples. Unfortunately, different sampling methods prohibit the ability to run one ordination of all fish catch. However, catch from gillnets was compared to the same environmental variables as the trawl dataset. For both the trawl and gillnet ordinations, the fish group datasets were relativized by species maximum to equalize common and uncommon species.

Lastly, the distribution of predator groups was related to the distribution and abundance of prey groups. In ArcGIS, rasters of all 11 prey groups used in the NMDS analysis were created for each zone and year combination based on catch rates from trawls or gillnet sets, using an IDW interpolation and $50 \mathrm{~m}$ cell size. The location of each predator sighting was used to sample the corresponding temporal set of prey rasters to capture relative prey density values at each predator sighting. All values of prey density were log transformed $(\log +1)$. This dataset was used to examine the differences in the distribution between predator and prey groups using Kruskal-Wallis tests and box plots. The family Mugilidae was not included in this analysis because mullet was not sampled in Florida Bay during the same time period as these predator surveys, preventing any distribution comparison.

\section{RESULTS}

Results from the 3-way ANOVA indicated that variation in sighting rates of each predator group was consistently associated with zone (exception: foraging dolphin) and bottom type, but never the factor year (Table 5). This result justifies grouping the data from all 3 yr for the Mantel tests and ordinations. The sighting rates in mudbank habitat were significantly different for each predator group except non-foraging dolphins (Fig. 4a). Osprey and pelicans sighting rates were significantly greater in the Flamingo zone (Fig. $4 b)$. Observations of cormorants were greatest in every zone, with exceptionally high concentrations in the Atlantic zone (Fig. 4b).

The pure partial Mantel tests indicated that 8 out of 13 explanatory variables were significantly correlated with the presence/absence of the 6 predator groups once spatial autocorrelation was accounted for: zone, chl $a$, salinity, turbidity, depth, mudbank, mud and sand $(p<0.001)$. Space (the $x y$ coordinates) was marginally non-significant ( $p=0.063)$, indicating that the
Table 5. Three-way ANOVA results for the sighting rate of each predator group as associated with the factors zone, year and bottom type. Pairwise comparisons conducted with a Tukey test $(\alpha<0.05)$. Zone codes: $\mathrm{A}=$ Atlantic, $\mathrm{C}=\mathrm{Central}$, $\mathrm{E}=$ Eastern, $\mathrm{F}=$ Flamingo, $\mathrm{W}=$ Western. Bottom type codes: $\mathrm{H}=$ hardbottom, HBSG = hardbottom with seagrass, $\mathrm{MB}=$ mudbank, $\mathrm{M}=$ mud, $\mathrm{S}=$ sand, $\mathrm{SG}=$ seagrass

\begin{tabular}{|lrrl|}
\hline Species group & $F$ & $\mathrm{p}$ & $\begin{array}{l}\text { Significant pairwise } \\
\text { comparisons }\end{array}$ \\
\hline Cormorant & & & \\
Zone & 2.757 & 0.028 & A-W \\
Year & 1.046 & 0.359 & \\
Bottom type & 4.244 & 0.003 & MB-S, MB-H, MB-M \\
Foraging dolphin & & \\
Zone & 1.515 & 0.202 & \\
Year & 1.138 & 0.329 & \\
Bottom type & 3.35 & 0.011 & MB-H, MB-S, MB-HBSG \\
Non-foraging & dolphin & & \\
Zone & 4.091 & 0.003 & C-W, A-W \\
Year & 2.033 & 0.142 & \\
Bottom type & 2.406 & 0.05 & - \\
Osprey & & & \\
Zone & 8.398 & $<0.001$ & F-all zones but C \\
Year & 1.476 & 0.238 & \\
Bottom type & 7.512 & $<0.001$ & MB-all bottom types \\
Pelican & & & \\
Zone & 3.461 & 0.009 & F-E \\
Year & 2.125 & 0.130 & \\
Bottom type & 6.9 & $<0.001$ & MB-all bottom types \\
Tern & & & \\
Zone & 4.2 & 0.003 & C-W, C-A \\
Year & 1.517 & 0.229 & \\
Bottom type & 6.255 & $<0.001$ & MB-all bottom types but M \\
& & & \\
\hline
\end{tabular}

majority of the variation in species distribution was explained by the explanatory variables. All bottom type characteristics (including those not found to be significant in the Mantel tests) were included in the NMDS ordination of predator group habitat use patterns. This choice was made to facilitate contrast with the significant bottom types of mud, mudbank and sand. If species were not found in these bottom types, it was reasoned that they must be in seagrass, hardbottom or hardbottom with seagrass habitats, and therefore important to include in the ordination.

The predator groups associated differently with the 2 axes produced by the NMDS, which accounted for $88 \%$ of the variability observed in the structure of predator group distribution in habitat space (Fig. 5). Mud, turbidity, depth and hardbottom were the explanatory variables most correlated with the both axes (Table 6). The variability in chl a concentration was also captured in both axes, and the influence of mudbank and seagrass habitats was described by the gradient along Axis 1. Predator groups occupy different habitat space within this ordination plot. Cor- 


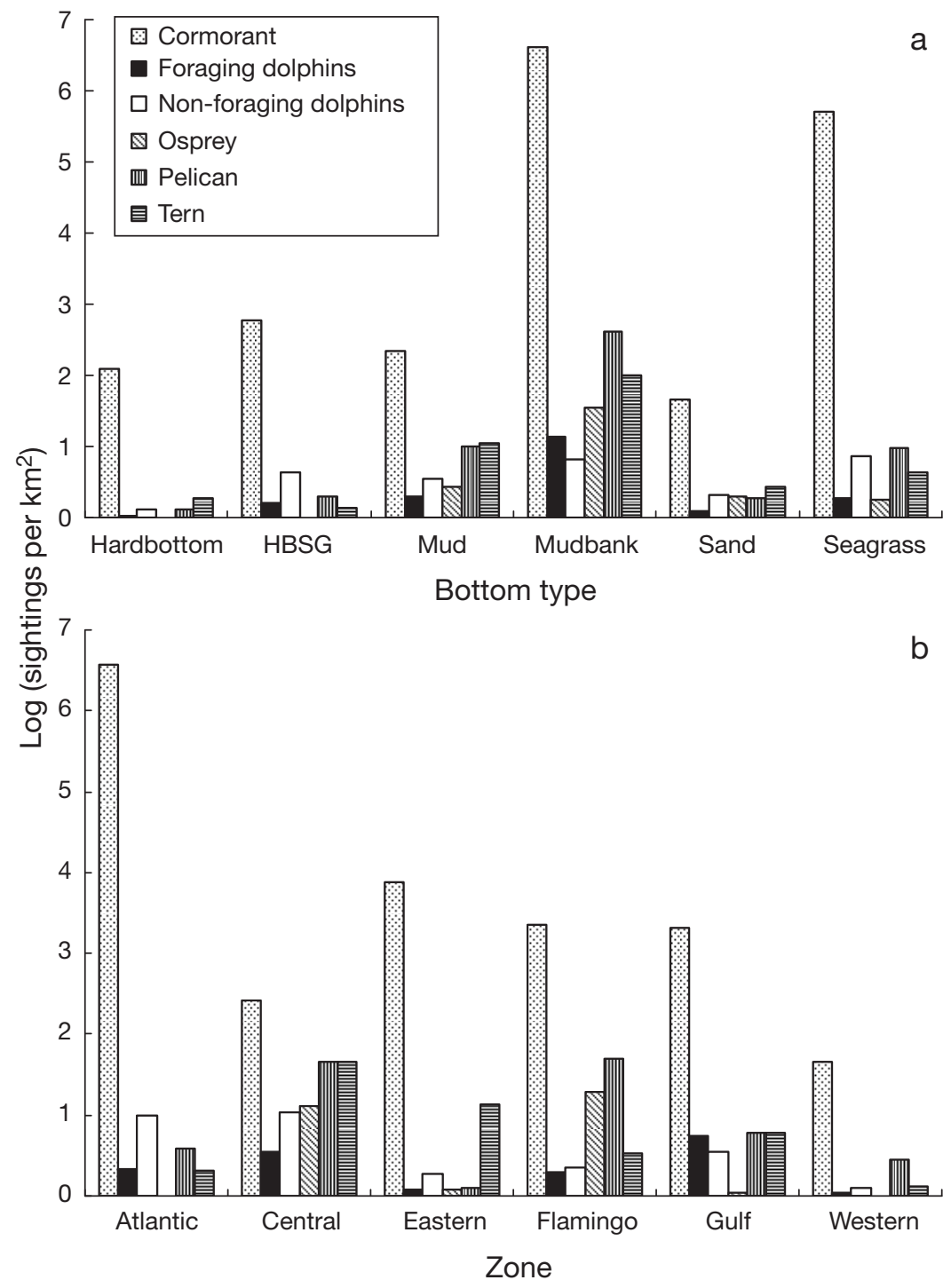

Fig. 4. Sighting rates, accounting for survey effort, of each predator group by (a) bottom type and (b) zone. HBSG = hardbottom with seagrass groups associated variably with each axis. The explanatory capacity of the categorical variables bottom type and zone were not included in the ordination. However, once symbolized by these grouping variables (Fig. 7), the distribution of trawl samples within the ordination space fell along gradients of bottom type and zone. Trawls on the left side of the ordination plot were predominantly conducted in mud or mudbank habitats within the Central and Eastern zones. This result is in contrast with trawls performed in deeper habitats on the right side of the plot which primarily sampled sand, hardbottom or hardbottom with seagrass habitats in the Gulf and Atlantic zones.

Catfish (family Ariidae) and jacks (family Carangidae) occupied opposite corners of the 2 axes NMDS ordination plot that cumulatively explained $85 \%$ of the variation in fish catch by gillnet sets (Table 7). Axis 1 and 2 explained 0.210 and 0.636 of the variation in distribution between fish groups within habitat space, respectively. Catfish were caught in shallower water, closer to mudbanks, with higher chl $a$ and turbidity levels. Conversely, jacks associated with deeper habitat, further from mudbanks, with lower chl a and turbidity levels. Because the categorical variable bottom type could not be integrated into the ordination, 'distance from mudbank' can be considered a proxy for the relative amount of mudbank bottom type available at each sampling site. morants were in deeper water with less mud, turbidity and chl $a$ and a greater proportion of hardbottom and seagrass habitat. This is in contrast to foraging dolphins, which were observed in shallow, muddy, turbid, productive waters with low seagrass. Non-foraging dolphins, however, were found in habitats characterized by deeper water with relatively lower levels of mud, turbidity, and chl $a$, and greater hardbottom and seagrass habitat. Osprey and pelicans plotted in similar habitat space as foraging dolphins.

Two axes were also selected by the NMDS run on the trawl data, which cumulatively explained $51 \%$ of the variation. Depth was the dominant explanatory variable of fish group distribution (Fig. 6, Table 7). $\mathrm{Chl} a$, temperature and turbidity variation explained a small portion of the gradient along Axis 2. The fish
Table 6. Pearson's correlation coefficients between ordination axes and explanatory variables from 2D NMDS ordination of the 6 predator groups

\begin{tabular}{|c|c|c|}
\hline \multirow[t]{2}{*}{ Variable } & \multicolumn{2}{|c|}{$\begin{array}{c}\text { Pearson's correlation } \\
\text { coefficient }\end{array}$} \\
\hline & Axis 1 & Axis 2 \\
\hline Chl a & -0.153 & -0.127 \\
\hline Salinity & 0.044 & -0.001 \\
\hline Turbidity & -0.232 & -0.173 \\
\hline Depth & 0.219 & -0.003 \\
\hline Seagrass & 0.132 & 0.045 \\
\hline Mudbank & -0.192 & 0.014 \\
\hline Mud & -0.253 & -0.197 \\
\hline Sand & -0.075 & -0.094 \\
\hline Hardbottom & 0.219 & 0.159 \\
\hline Hardbottom with seagrass & 0.089 & 0.027 \\
\hline
\end{tabular}




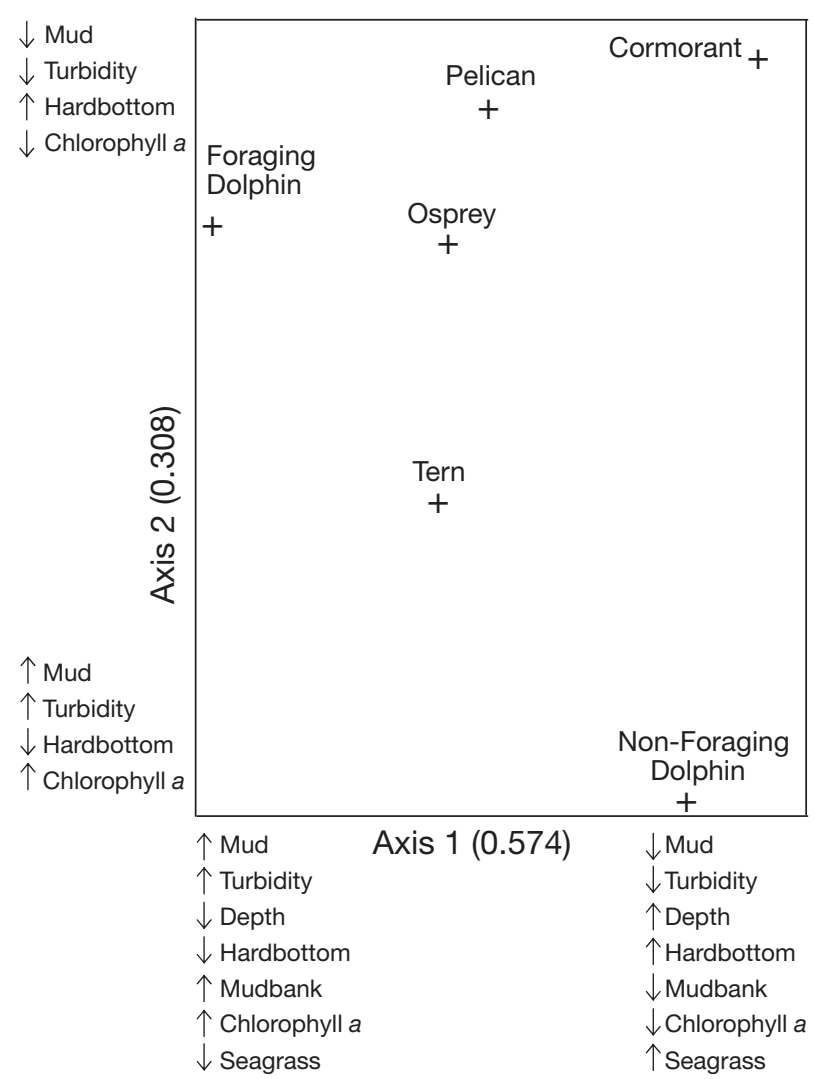

Fig. 5. NMDS plot showing the habitat use patterns of the 6 predator groups examined. Plus signs indicate where the groups fall in ordination space. The list of variables at the edge of each axis, and accompanying arrows, indicate the variables, and their direction of magnitude, that characterize each axis. These lists are in order from most to least significant based on Pearson's correlation coefficients. The amount of variation explained by each axis is in parentheses

A backwards selection GAM of mullet catch returned bottom type and depth as the significant predictor variables. Although the $\mathrm{r}^{2}$ value for this model was only 0.38 , the p-value of depth was 0.06 and the GAM plot of mullet catch versus depth depicts decreasing catch rates with increasing water depth (Fig. 8a). The plot of bottom type relative to mullet catch shows greater catch rates in mud and mudbank habitats (Fig. 8b).

The Kruskal-Wallis tests determined that all predator groups had significantly different relationships with each prey group (Table 8). The box plots illustrate how these relationships varied by prey group (Fig. 9). Foraging dolphins and osprey were distributed in areas with high densities of catfish (Ariidae). Sighting rates of osprey were relatively lower than other predator groups when compared to the distribution of pinfish and porgies (Sparidae). The median value of gulf toadfish (Opsanus beta) was highest for dolphin and osprey sightings with cormorants also observed in areas with

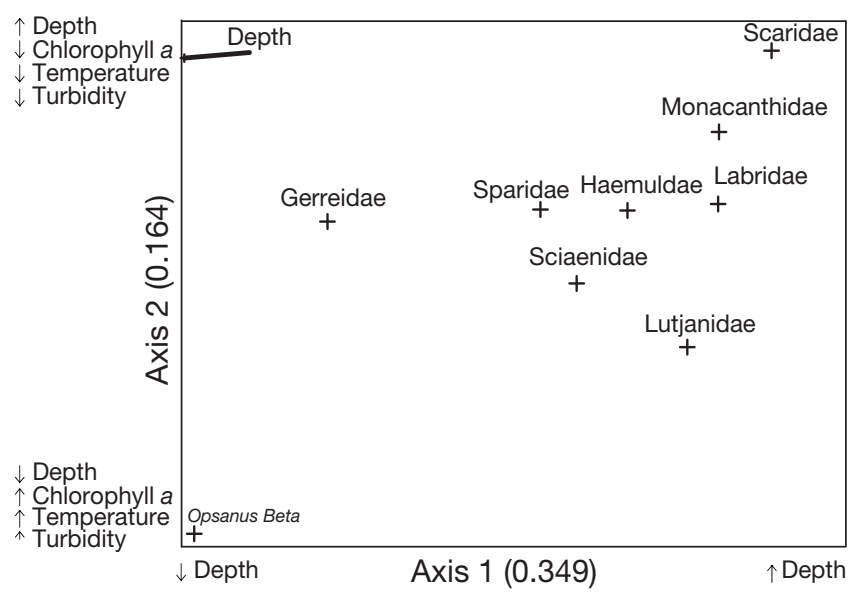

Fig. 6. NMDS plot of trawl data, describing the distribution of 9 fish groups in habitat space. The amount of variation explained by each axis is in parentheses. Plus signs indicate where the fish groups fall in ordination space. The list of variables at the edge of each axis, and accompanying arrows, indicate the variables, and their direction of magnitude, that characterize each axis. These lists are in order from most to least significant based on Pearson's correlation coefficients

Table 7. Pearson's correlation coefficients between ordination axes and explanatory variables from 2D NMDS ordination on trawl catch data and gillnet catch data

\begin{tabular}{|c|c|c|c|c|}
\hline \multirow{3}{*}{ Variable } & \multicolumn{4}{|c|}{ Pearson's correlation coefficient } \\
\hline & \multicolumn{2}{|c|}{ Trawl catch data } & \multicolumn{2}{|c|}{ Gillnet catch data } \\
\hline & Axis 1 & Axis 2 & Axis 1 & Axis 2 \\
\hline Depth & 0.475 & 0.140 & 0.182 & 0.249 \\
\hline Temperature & 0.046 & -0.126 & 0.076 & -0.150 \\
\hline Salinity & 0.090 & -0.016 & 0.158 & -0.096 \\
\hline Chl a & -0.007 & -0.132 & -0.291 & -0.255 \\
\hline Turbidity & 0.050 & -0.118 & -0.160 & -0.229 \\
\hline $\begin{array}{l}\text { Distance from } \\
\text { mudbank }\end{array}$ & -0.019 & 0.032 & 0.320 & 0.102 \\
\hline
\end{tabular}

relatively high densities of toadfish. Cormorant distribution was greater relative to other predator groups in areas of higher densities of wrasses (Labridae), snappers (Lutjanidae), filefish (Monacanthidae) and parrotfish (Scaridae). These trends correspond well with the diet tendencies of these predators (Table 2).

\section{DISCUSSION}

The ordination of the 6 predator groups described foraging dolphins, osprey and pelicans occupying similar habitat space: shallow, turbid, productive waters with high proportions of mud and mudbank bottom types (Fig. 5). These 3 predators also share common dominant prey items in Florida Bay, mullet and catfish, which were also described as occupying habitats of similar character- 


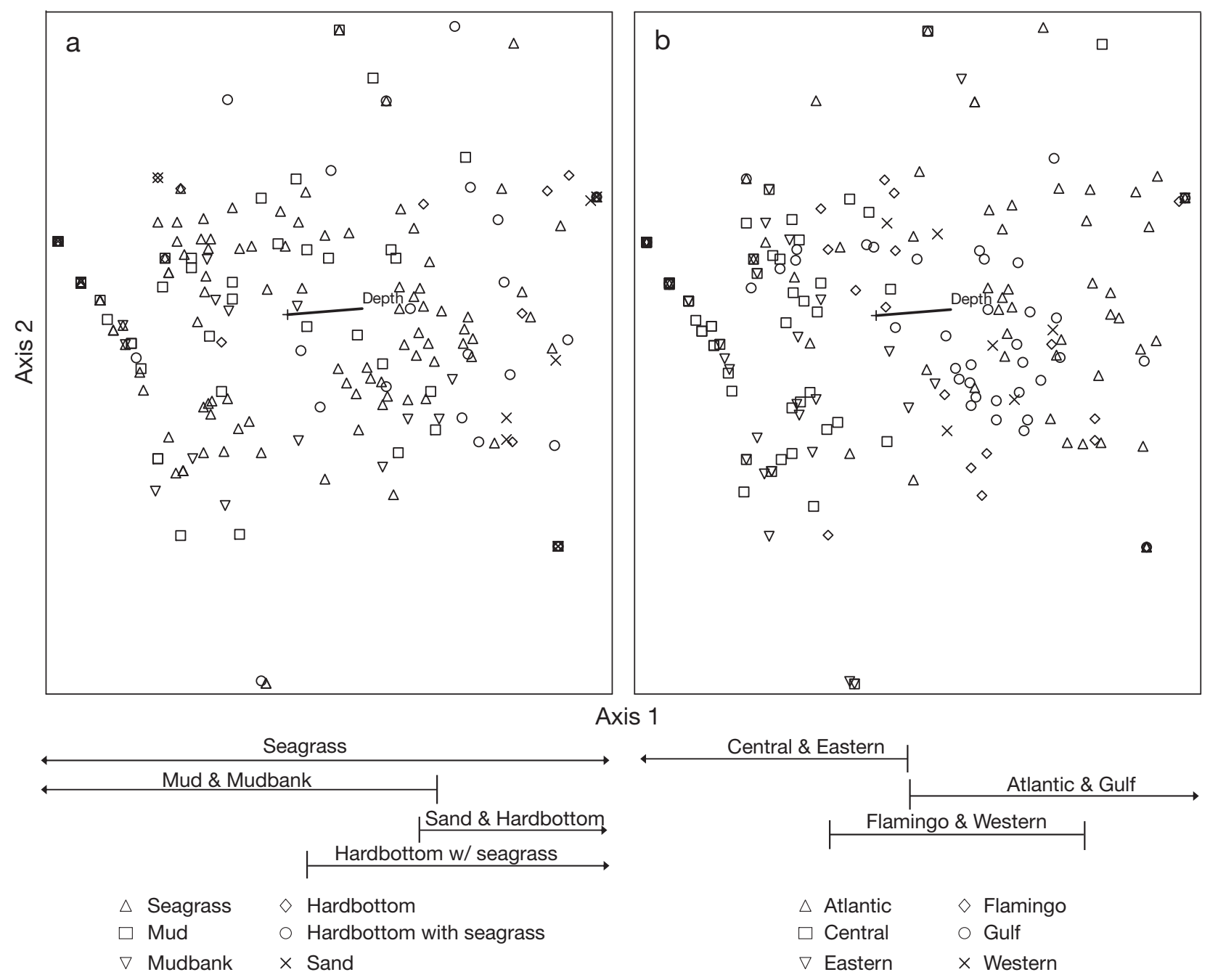

Fig. 7. Distribution of trawl samples within the habitat space created by the 2D NMDS on 9 fish groups, symbolized by (a) bottom type and (b) zone. Arrows below plots describe the general distribution of trawls by categorical group(s)

istics (Fig. 8). Moreover, foraging dolphins and osprey were sighted most frequently in habitats with higher densities of catfish compared to other predator groups (Fig. 10). Within the Central and Flamingo zones of Florida Bay, where mud and mudbank habitats dominate, there is potential for competition between dolphins, osprey and pelicans for mullet and/or catfish prey. This competition is likely diluted by variation in foraging tactics used by the predators to capture their prey: (1) dolphins in Florida Bay employ a unique, cooperative foraging tactic to corral mullet and force them to jump out of the water where they wait with open mouths to catch the mullet out of the air (Torres \& Read in press); (2) osprey dive feet first after prey and penetrate a maximum on $1 \mathrm{~m}$ below the surface (Poole 1989); and (3) the dominant foraging tactic of pelicans is to plunge about 1 to $2 \mathrm{~m}$ into the water column and 'gulp' up prey in their pouch (Gunter 1958, Johnsgard 1993). Throughout the field- work, it was not uncommon to witness dolphins, osprey and pelicans foraging together. In fact, $10 \%$ of all osprey sightings and $5 \%$ of all pelican sightings were observed at foraging dolphin sightings, compared to $3 \%$ of tern and $1 \%$ of cormorant sightings. Poole $(1989$, p. 78) described this scene:

'On Florida Bay, I have watched [osprey], six or eight at a time, hovering together over schools of mullet that [dolphins] (Tursiops truncatus) had driven into shallow water. Brown Pelicans (Pelicanus occidentalis) and various gulls often joined the diving melee, a pleasing kaleidoscope of mammal, bird, and fish...'

Other significant prey items of dolphins in Florida Bay are gulf toadfish Opsanus beta, mojarra (family Gerreidae), pinfish Lagodon rhomboides (family Sparidae), grunts and pigfish (family Haemulidae), and silver perch Bairdiella chrysoura and spotted seatrout Cynoscion nebulosus (family Sciaenidae). These prey items were 

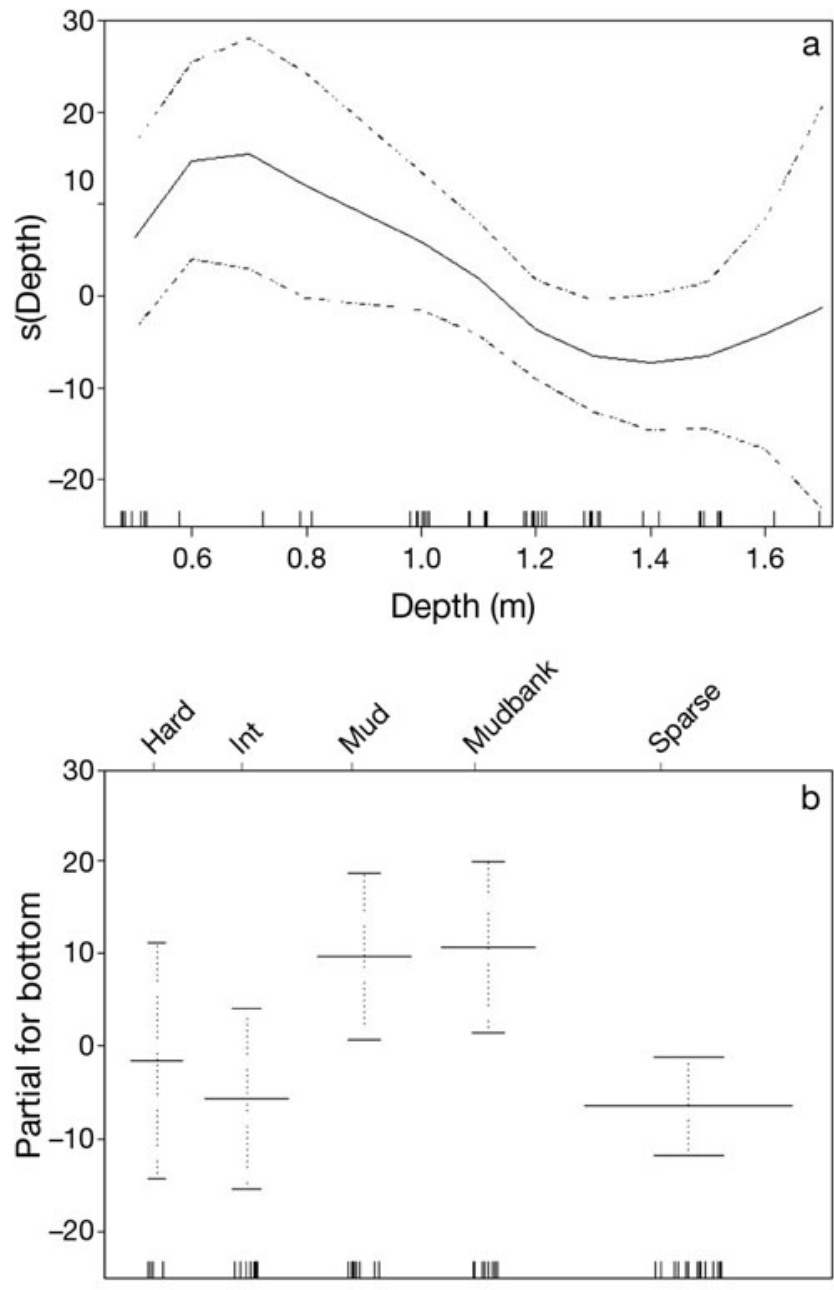

Bottom type

Fig. 8. Generalized additive model (GAM) plots of mullet catch versus (a) depth and (b) bottom type. Ticks on the $x$-axis represent sampling intensity. The dashed lines bracketing the response curve are twice the SE and function as confidence limits of the model. Hard = hardbottom, Int = intermediate seagrass, Sparse $=$ sparse seagrass

Table 8. Kruskal-Wallis test results comparing the relationship between each prey group to the 6 predator groups.

\begin{tabular}{|lrr|}
\hline Prey group & Kruskal-Wallis chi-squared & $\mathrm{p}$ \\
\hline Ariidae & 243.7999 & $<0.001$ \\
Carangidae & 60.7523 & $<0.001$ \\
Gerreidae & 41.6641 & $<0.001$ \\
Haemulidae & 110.0328 & $<0.001$ \\
Labridae & 249.6358 & $<0.001$ \\
Lutjanidae & 199.0336 & $<0.001$ \\
Monacanthidae & 184.6408 & $<0.001$ \\
Opsanus beta & 22.5032 & 0.001 \\
Scaridae & 220.4145 & $<0.001$ \\
Scianidae & 32.4779 & $<0.001$ \\
Sparidae & 24.9234 & 0.001 \\
\hline
\end{tabular}

commonly caught in trawls conducted in Florida Bay and, similar to their dolphin predators, the ordination determined their dominant habitat space to be relatively shallow waters with high chl a and turbidity levels, composed of mud and mudbank habitats (Figs. $6 \&$ 7). This is in contrast to 3 of the major prey items of cormorants: parrotfish (family Scaridae), filefish (family Monacanthidae) and snapper (Family Lutjanidae). These 3 groups of prey items were caught in deeper habitats with lower chl $a$ and turbidity levels, in seagrass, sand, hardbottom or hardbottom with seagrass bottom types of the Atlantic and Gulf zones. These habitat characteristics correspond with the habitat conditions described for cormorants by the predator group ordination: deeper water with low chl $a$ and turbidity levels, less mud and mudbank habitat, and a greater proportion of hardbottom and seagrass bottoms (Fig. 5).

While cormorants, like dolphins, are also known to consume gulf toadfish, pinfish, grunts and pigfish, cormorants in Florida Bay may concentrate their foraging behavior on prey items with less interspecific competition. Although cormorants inhabit all regions of Florida Bay and had the highest sighting rates in each zone, cormorant sighting rates were especially dominant in areas of Florida Bay where mud and mudbank bottom types are minimal (Fig. 4b). In the muddy regions of the Central, Flamingo and Western zones, sighting rates of dolphins, osprey, pelicans and terns rivaled that of cormorants in these areas. Of the predator species examined in the present study, only dolphins and cormorants are able to exploit benthic prey items. Osprey, pelicans and terns are limited to surface prey. Therefore, cormorants in Florida Bay may concentrate their foraging efforts on less competitive prey items (non-dolphin prey) and occur more frequently where these prey items dominate. It is possibly for this reason that cormorants and foraging dolphins occupy habitats with very disparate characteristics. Evidence of this potential habitat separation can be seen in the box plots (Fig. 10) depicting more frequent observations of cormorants than foraging dolphin sightings in habitats with higher densities of non-dolphin prey (Labridae, Lutjanidae, Monacanthidae, Scaridae). Likewise, observations of cormorants occurred less frequently than foraging dolphin sightings in habitats of non-cormorant prey (Ariidae, Carangidae, Scianidae). Common prey items of both cormorants and dolphins (Sparidae, Haemulidae, Opsanus beta) were frequently caught throughout Florida Bay, which may explain the similar sighting rates of these 2 predators relative to the density of these prey items.

Prey size can also influence resource partitioning between predators. Dolphins generally pursue larger ( 35 to $350 \mathrm{~mm}$ ) prey than cormorants $(<150 \mathrm{~mm}$ ), with some overlap in size range (Barros 1993, Johnsgard 

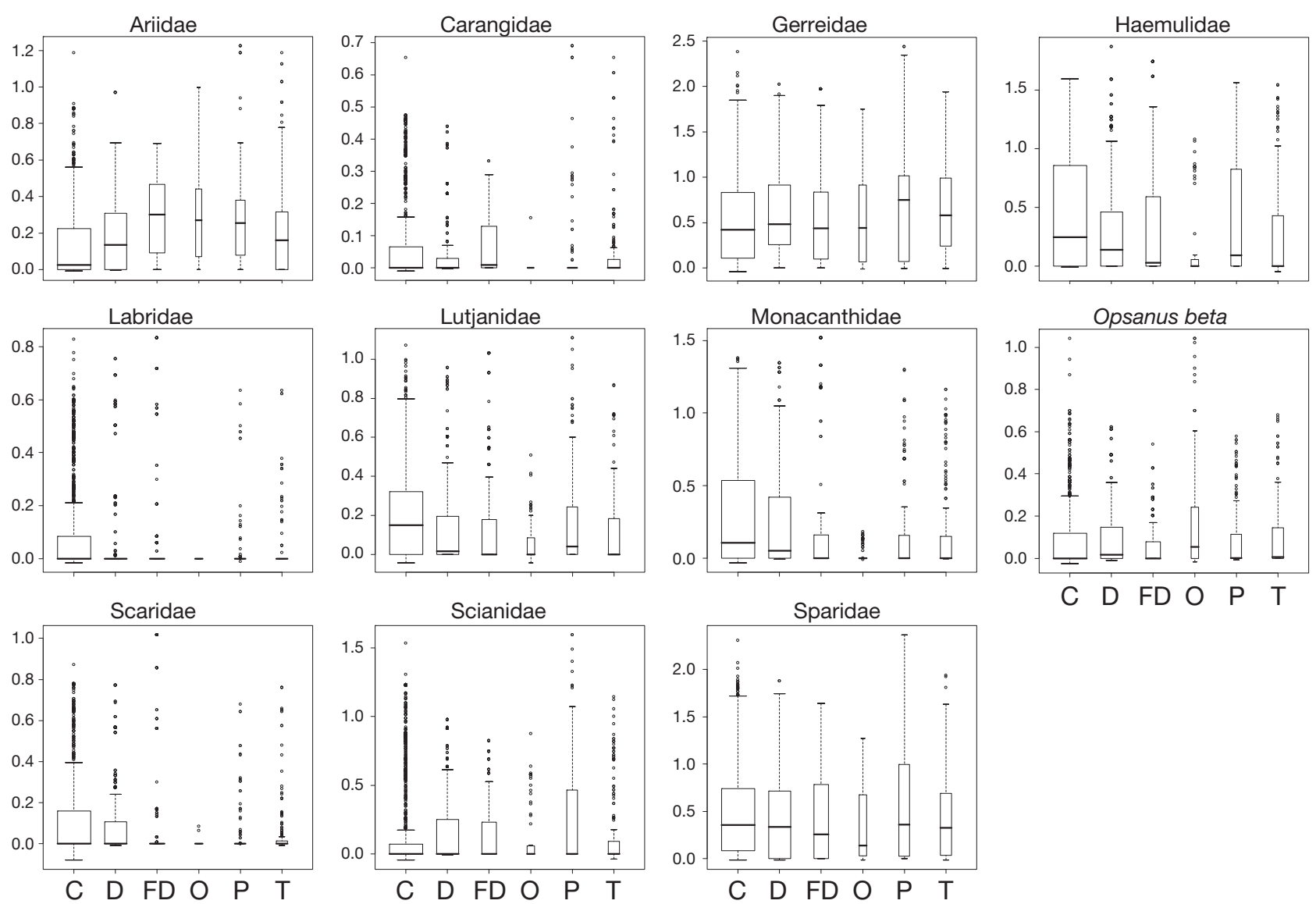

Fig. 9. Box plots illustrating the relationship between the distribution of each predator group and each prey group. The $y$-axes on each plot are different and represent $\log +1$ values of the prey group density. Boxes are drawn with widths proportional to the number of observations in each group. Boxes represent the $95 \%$ confidence interval. The line through each box indicates the median and circles represent outliers. $\mathrm{C}=$ cormorant, $\mathrm{D}=$ dolphin, $\mathrm{FD}=$ foraging dolphin, $\mathrm{O}=$ osprey, $\mathrm{P}=$ pelican, $\mathrm{T}=$ tern

1993, Barros \& Wells 1998). This mechanism of prey division may provide a less competitive foraging niche for cormorants in the mud and mudbank habitats of Florida Bay and help to explain their continued use of these habitats. However, the prey items of osprey (250 to $350 \mathrm{~mm}$ ) and pelicans (64 to $257 \mathrm{~mm}$ ) are within the same size range as dolphins, which increases the potential for competition between these predators for mullet and/or catfish (Poole 1989, Pinson \& Drummond 1993).

The contrasting habitat space of foraging and nonforaging dolphins indicates that the behavior states of all non-foraging dolphins (travel, socialize, rest or unknown) in Florida Bay do not require the same habitat characteristics as foraging habitat. When foraging, dolphins are constrained by the habitat of their prey items, making it necessary to sometimes incur an added cost of increased predation risk or competition from other predators (Hugie \& Dill 1994, Sih 1998). Dolphins may avoid these habitats when not foraging, promoting a difference in habitat use patterns.
The habitat space of terns fell in the middle of the ordination plot with no other predator group in close proximity. Additionally, the prey items of terns could not be included in the analyses, mainly for lack of occurrence in fish sampling effort. Based on these 2 factors, it is difficult to draw conclusions about the habitat use of terns relative to other predators and their prey items in Florida Bay. However, similar to the other predator groups examined, except non-foraging dolphins, the sighting rate of terns increased in mud and mudbank bottom types (Fig. 4a).

Throughout the analyses, depth and bottom type variation consistently manifested as significant predictor variables. These static, benthic descriptors influenced the distribution of the 6 predator groups, fish catch from trawls, fish catch in gillnet sets and mullet catch from seines. Previous research in Florida Bay has also documented depth as a significant factor in the distribution of seagrass (Hall et al. 1999, Landry 2005), hardbottom (Shinn et al. 1994) and mudbank (Powell et al. 1989) habitats, impacting crustacean (Holmquist 
et al. 1989a) and fish (Sogard et al. 1989a, Thayer \& Chester 1989) communities.

Depth variation in Florida Bay is a result of subtle irregularities in the bedrock topography, which, among other impacts, directly influences mudbank location and formation (Wanless \& Tagett 1989). The present study documents the importance of mudbank habitat for top predators within this ecosystem; all 4 seabird groups and foraging dolphins were observed most frequently in mudbank habitat. These seagrasscovered mudbanks concentrate diverse faunal communities in a narrow (shallow) water column (Holmquist et al. 1989b, Sogard et al. 1989b) which attract a variety of predators. Due to the concentration of prey in mudbank habitats, habitat use patterns of top predators overlap and may influence competition. Therefore, these predators must partition resources through other mechanisms such as prey size (i.e. dolphins and cormorants), foraging tactic (i.e. dolphins, osprey and pelicans), or prey item (i.e. dolphins and terns). Additionally, since temporal and spatial scales were largely unaccounted for in this analysis, it is also possible that predators minimize interspecific competition through spatial and/or temporal habitat segregation. In summary, shifts in bathymetric structure and bottom type influence the floral and faunal communities in Florida Bay, which subsequently affects the distribution of top predators such as cormorants, osprey, pelicans, terns and foraging dolphins. These results highlight the importance of shallow mudbanks in Florida Bay and raise questions about the effects of expected sea level rise on the ecology of these top predator populations.

Despite Florida Bay's extreme habitat heterogeneity, there was high habitat overlap between predators within one particular habitat: the productive seagrasscovered mudbanks. Application of Pianka's (1974) 'niche overlap hypothesis' to this pattern of strong niche overlap by predators implies that prey resources may not have been limiting during the time period of the present study. Or, the diversity of foraging tactics and target prey items and sizes provided ample 'niche dimensions' to adequately partition the resources and foster 'diffuse competition'. An insightful companion study to these results would be to conduct this research during a time of low prey availability in Florida Bay. It is expected that these predators would exhibit less habitat overlap and concentrate habitat use patterns in niches most suited to their foraging behaviors and prey items. In a scenario of limited prey, a little bit of competitive inhabitation by many species (diffuse competition) can be equivalent to strong competition between a few species (Pianka 1974).

Acknowledgements. This research was conducted under Everglades National Park permits EVER-2003-SCI-0042, EVER2004-SCI-0062, and EVER-2005-SCI-0062, General Authoriza- tions 911-1466 and 572-1639, and approved by the Duke University Institutional Animal Care \& Use Committee (IACUC). Data were provided by the SERC-FIU Water Quality Monitoring Network which is supported by SFWMD/ SERC Cooperative Agreement \#C-15397 as well as EPA Agreement \#X994621-940 . Mullet data was supplied by the Fisheries Independent Monitoring Program of the Florida Fish and Wildlife Conservation Commission. Funding and support was provided by the NOAA/Coastal Ocean Program, the Dolphin Ecology Project, the Florida Keys National Marine Sanctuary and the Duke University Marine Lab. I am grateful to D. Hyrenbach for introducing me to seabird ecology and his assistance in setting up my sampling protocol. N. Barros, D. Gannon, R. Schick, N. Cagle, P. Halpin and K. Flaherty provided helpful guidance on diet information, analysis and mullet ecology. I thank T. Chandler, K. Freeman, E. Morehouse, A. Starling and M. Worthington for assistance with field work, and A. J. Read and 2 anonymous reviewers for constructive comments on this manuscript.

\section{LITERATURE CITED}

Audubon (1972) Brown pelican population ecology, Florida. Audubon, Tavernier, FL

Baltz DM, Morejohn GV (1977) Food habits and niche overlap of seabirds wintering on Monterey Bay, California. Auk 94:526-543

Barros NB (1987) Food habits of bottlenose dolphins (Tursiops truncatus) in the southeastern United States, with special reference to Florida waters. MSc thesis, University of Miami

Barros NB (1993) Feeding ecology and foraging strategies of bottlenose dolphins on the central east coast of Florida. $\mathrm{PhD}$ thesis, University of Miami

Barros NB, Wells RS (1998) Prey and feeding patterns of resident bottlenose dolphins (Tursiops truncatus) in Sarasota Bay, Florida. J Mammal 79:1045-1059

Beals E (1984) Bray-Curtis ordination: an effective strategy for analysis of multivariate ecological data. Adv Ecol Res 14:1-55

Bent AC (1921) Life histories of North American gulls and terns. Bulletin 113. Smithsonian Institution, Washington, DC

Boyer JN, Fourqurean JW, Jones RD (1999) Seasonal and long-term trends in the water quality of Florida Bay (1989-1997). Estuaries 22:417-430

Connell JH (1961) The influence of interspecific competition and other factors on the distribution of the barnacle Chthamalus stellatus. Ecology 42:710-723

Cummings MV (1987) The feeding energetics of the doublecrested cormorant in Biscayne Bay, Florida. University of Miami, Miami, FL

Fauchald PK, Erikstad E, Skarsfjord H (2000) Scale-dependent predator-prey interactions: the hierarchical spatial distribution of seabirds and prey. Ecology 81:773-783

Fogarty MJ, Nesbitt SA, Gilbert CR (1981) Diet of nesting Brown Pelicans in Florida. Fla Field Nat 9:38-40

Fretwell SD, Lucas HL Jr (1970) On territorial behavior and other factors influencing habitat distribution in birds I. Theoretical development. Acta Biotheor 19:16-36

FWC-FWRI (2007) Fisheries-independent monitoring program procedure manual. Florida Fish and Wildlife Research Institute, St. Petersburg, FL

Gunter G (1958) Feeding behavior of brown and white pelicans of the Gulf coast of the United States. Louisiana Acad Sci 21:34-39

> Hall MO, Durako M, Fourqurean JW, Zieman JC (1999) Decadal changes in seagrass distribution and abundance in Florida Bay. Estuaries 22:445-459

Halley R, Prager E (1997) Florida Bay Bottom Types map. USGS Open-File Report, OFR 97-526, St. Petersburg, FL, 
US Geological Survey. http://sofia.usgs.gov/publications/ ofr/97-526/

Heck KL Jr, Orth RJ (1980) Seagrass habitats: the roles of habitat complexity, competition and predation in structuring associated fish and motile macroinvertebrate assemblages. In: Kennedy VS (ed) Estuarine perspectives. Academic Press, New York, p 449-464

Holmquist JG, Powell GVN, Sogard SM (1989a) Decapod and stomatopod assemblages in an unusual system of seagrasscovered mud banks in Florida Bay. Mar Biol 100:473-483

Holmquist JG, Powell GVN, Sogard SM (1989b) Sediment, water level and water temperature characteristics of Florida Bay's grass-covered mud banks. Bull Mar Sci 44:348-364

Hugie DM, Dill LM (1994) Fish and game: a game theoretic approach to habitat selection by predators and prey. J Fish Biol 45:151-169

Hyrenbach KD, Veit RR, Weimerskirch H, Hunt GLJ (2006) Seabird associations with mesoscale eddies: the subtropical Indian Ocean. Mar Ecol Prog Ser 324:271-279

Hyrenbach KD, Veit RR, Weimerskirch H, Metzl N, Hunt GLJ (2007) Community structure across a large-scale ocean productivity gradient: marine bird assemblages of the Southern Indian Ocean. Deep-Sea Res I 54:1129-1145

> Jaquemet S, Corre ML, Marsac F, Potier M, Weimerskirch H (2005) Foraging habitats of the seabird community of Europa Island. Mar Biol 147:573-582

Johnsgard PA (1993) Cormorants, darters, and pelicans of the world. Smithsonian Institution Press, Washington, DC

Kruskal JB (1964) Nonmetric multidimensional scaling: a numerical method. Psychometrika 29:115-129

Landry B (2005) Changes in the distribution and density of Florida Bay macrophytes: 1995-2004. University of North Carolina, Wilmington, NC

MacArthur RH (1958) Population ecology of some warblers of northeastern coniferous forests. Ecology 39:599-619

MacArthur RH (1972) Geographical ecology: patterns in the distribution of species. Harper and Row, New York

Mantel N (1967) The detection of disease clustering and a generalized regression approach. Cancer Res 27:209-220

May RM, MacArthur RH (1972) Niche overlap as a function of environmental variability. Proc Natl Acad Sci USA 69: $1109-1113$

McCune B (1994) Improving community analysis with the Beals smoothing function. Ecoscience 1:82-86

McCune B, Mefford MJ (1999) PC-ORD. Multivariate analysis of ecological data. MjM Software Design, Gleneden Beach, OR

McGinnis TW, Emslie SD (2001) The foraging ecology of royal and sandwich terns in North Carolina, USA. Waterbirds 24:361-370

McIvor CC, Ley JA, Bjork RD (1994) Changes in freshwater inflow from the Everglades to Florida Bay including effects on biota and biotic processes: a review. In: Davis SM, Ogden JC (eds) Everglades: the ecosystem and its restoration. St. Lucie Press, Delrey Beach, FL, p 117-146

Ogden JC (1973) Preliminary report on a study of Florida Bay osprey. Everglades National Park, Homestead, FL

Ogden JC (1978) Birds. In: Kale HW II (ed) Rare and endangered biota of Florida, Vol 2. University of Florida, Gainesville, FL, p 31-32

Pianka ER (1974) Niche overlap and diffuse competition. Proc Natl Acad Sci USA 71:2141-2145

Pinson D, Drummond H (1993) Brown pelican siblicide and the prey-size hypothesis. Behav Ecol Sociobiol 32:111-118

Poole AF (1989) Ospreys: a natural and unnatural history. Cambridge University Press, Cambridge

Powell GVN, Holmquist JG, Sogard SM (1989) Physical and environmental characteristics of Florida Bay with empha- sis on mud banks. Bull Mar Sci 44:522

Redfern JV, Ferguson MC, Becker EA, Hyrenbach KD and others (2006) Techniques for cetacean-habitat modeling. Mar Ecol Prog Ser 310:271-295

Schneider D, Piatt JF (1986) Scale-dependent correlation of seabirds with schooling fish in a coastal ecosystem. Mar Ecol Prog Ser 32:237-246

Schoener TW (1971) Theory of feeding strategies. Annu Rev Ecol Syst 2:369-404

Scott GP, Dewey MR, Hansen LJ, Owen RE, Rutherford ES (1989) How many mullet are there in Florida Bay? Bull Mar Sci 44:89-107

> Shepard RN (1962) The analysis of proximities: multidimensional scaling with an unknown distance function. Psychometrika 27:125-139

Shinn E, Lidz B, Harris M (1994) Factors controlling distribution of Florida Keys Reefs. Bull Mar Sci 54:1084

Sih A (1998) Game theory and predator-prey response races. In: Dugatkin LA, Reeve HK (eds) Advances in game theory and the study of animal behavior. Oxford University Press, Oxford, p 221-238

Skov H, Prins E (2001) Impact of estuarine fronts on the dispersal of piscivorous birds in the German Bight. Mar Ecol Prog Ser 214:279-287

Skov H, Durinck J, Danielsen F, Bloch D (1995) Co-occurrence of cetaceans and seabirds in the northeast Atlantic. J Biogeogr 22:71-88

Sogard SM, Powell GVN, Holmquist JG (1989a) Spatial distribution and trends in abundance of fishes residing in seagrass meadows on Florida Bay mudbanks. Bull Mar Sci 44:179-199

Sogard SM, Powell GVN, Holmquist JG (1989b) Utilization by fishes of shallow, seagrass-covered banks in Florida Bay: 1. species composition and spatial heterogeneity. Environ Biol Fishes 24:53-65

Thayer GW, Chester AJ (1989) Distribution and abundance of fishes among basin and channel habitats in Florida Bay. Bull Mar Sci 44:200-219

Thayer GW, Powell GVN, Hoss DE (1999) Composition of larval, juvenile, and small adult fishes relative to changes in environmental conditions in Florida Bay. Estuaries 22: 518-533

Torres LG, Read AJ (in press) Where to catch a fish? The influence of foraging tactics on the ecology of bottlenose dolphins (Tursiops truncatus) in Florida Bay, Florida. Mar Mamm Sci 18:1702-1717

Torres LG, Heithaus MR, Delius B (2006) Influence of teleost abundance on the distribution and abundance of sharks in Florida Bay, USA. Hydrobiologia 569:449-455

Torres LG, Read AJ, Halpin P (in press) Fine-scale habitat modeling of a top marine predator: Do prey data improve predictive capacity? Ecol Appl 18:1702-1717

> Unterseher M, Tal O (2006) Influence of small scale conditions on the diversity of wood decay fungi in a temperate, mixed deciduous forest canopy. Mycol Res 110:169-178

- Vilchis LI, Ballance LT, Fiedler P (2006) Pelagic habitat of seabirds in the eastern tropical Pacific: effects of foraging ecology on habitat selection. Mar Ecol Prog Ser 315: 279-292

> Vlietstra LS (2005) Spatial associations between seabirds and prey: effects of large-scale prey abundance on small-scale seabird distribution. Mar Ecol Prog Ser 291:275-287

Wanless HR, Tagett MG (1989) Origin, growth and evolution of carbonate mudbanks in Florida Bay. Bull Mar Sci 44: $454-489$

Wiley TR, Simpfendorfer CA (2007) The ecology of elasmobranchs occurring in the Everglades National Park, Florida: implications for conservation and management. Bull Mar Sci 80:171-189 